\title{
A Systematic Review and Meta-Analysis of the Effect of Statins on Glutathione Peroxidase, Superoxide Dismutase, and Catalase
}

\author{
Angelo Zinellu ${ }^{1}$ (D) and Arduino A. Mangoni ${ }^{2,3, *(\mathbb{D})}$ \\ 1 Department of Biomedical Sciences, University of Sassari, 07100 Sassari, Italy; azinellu@uniss.it \\ 2 Discipline of Clinical Pharmacology, College of Medicine and Public Health, Flinders University, \\ Bedford Park, SA 5042, Australia \\ 3 Department of Clinical Pharmacology, Flinders Medical Centre, Southern Adelaide Local Health Network, \\ Bedford Park, SA 5042, Australia \\ * Correspondence: arduino.mangoni@flinders.edu.au
}

check for updates

Citation: Zinellu, A.; Mangoni, A.A. A Systematic Review and MetaAnalysis of the Effect of Statins on Glutathione Peroxidase, Superoxide Dismutase, and Catalase. Antioxidants 2021, 10, 1841. https://doi.org/ 10.3390/antiox10111841

Academic Editor: Ehab H Sarsour

Received: 22 October 2021

Accepted: 17 November 2021

Published: 19 November 2021

Publisher's Note: MDPI stays neutral with regard to jurisdictional claims in published maps and institutional affiliations.

Copyright: (c) 2021 by the authors. Licensee MDPI, Basel, Switzerland. This article is an open access article distributed under the terms and conditions of the Creative Commons Attribution (CC BY) license (https:// creativecommons.org/licenses/by/ $4.0 /)$.

\begin{abstract}
Statins may exert protective effects against oxidative stress by upregulating specific antioxidant mechanisms. We conducted a systematic review and meta-analysis of the effect of statins on three key antioxidant enzymes: glutathione peroxidase (GPx), superoxide dismutase (SOD), and catalase. The electronic databases PubMed, Web of Science, and Scopus were searched from inception to July 2021. The risk of bias was assessed with the Joanna Briggs Institute Critical Appraisal Checklist and certainty of evidence was assessed using the GRADE framework. In 15 studies, reporting 17 treatment arms in 773 patients (mean age 53 years, 54\% males), statins significantly increased the concentrations of both GPx (standardized mean difference, SMD $=0.80,95 \%$ confidence interval, CI 0.13 to 1.46, $p=0.018$; high certainty of evidence) and SOD (SMD $=1.54,95 \%$ CI 0.71 to 2.36, $p<0.001$; high certainty of evidence), but not catalase (SMD $=-0.16,95 \% \mathrm{CI}-0.51$ to $0.20, p=0.394$; very low certainty of evidence). The pooled SMD values were not altered in sensitivity analysis. There was no publication bias. In conclusion, statin treatment significantly increases the circulating concentrations of GPx and SOD, suggesting an antioxidant effect of these agents (PROSPERO registration number: CRD42021271589).
\end{abstract}

Keywords: statins; glutathione peroxidase; superoxide dismutase; catalase; oxidative stress; pleiotropic effects

\section{Introduction}

Elevations in circulating cholesterol concentrations significantly increase the risk of atherosclerosis and its clinical manifestations, particularly myocardial infarction, ischemic stroke, and peripheral arterial disease [1,2]. Statins, through the inhibition of the enzyme 3-hydroxy-3-methylglutaryl-CoA (HMG-CoA) reductase, the rate-limiting step in the mevalonate pathway through which cells synthesize cholesterol, are the most commonly prescribed drugs for the treatment of hypercholesterolaemia and the management of cardiovascular risk worldwide in view of their favourable efficacy and safety profile [3]. However, while the main action is mediated by lowering the concentrations of specific cholesterol fractions, particularly low-density lipoprotein (LDL) [4], the atheroprotective effects of statins involve other mechanisms, normally described as pleiotropic effects [5-7]. Such effects, generally apparent shortly after commencing statin treatment, have been shown to be mediated by specific antioxidant mechanisms [8-11].

Oxidative stress, through the generation of reactive oxygen species (ROS) and oxidized LDL, is considered to play a key pathophysiological role in the onset and the progression of atherosclerosis [12-14]. Specifically, oxidative stress exerts significant negative effects on cellular homeostasis by damaging lipids, thiols, DNA, and protein pools, stimulating 
the synthesis and release of pro-inflammatory and atherogenic cytokines, and favouring the adhesion of monocytes to the endothelium, a critical pathophysiological step in atherosclerosis and plaque formation $[15,16]$. The coexistence of oxidative stress and hypercholesterolemia imposes a particularly high burden on endothelial integrity, further increasing the risk of atherosclerosis and its clinical manifestations [17,18].

The effects of statin treatment, singly or in combination with other therapies, on oxidative stress have been extensively studied both in experimental models of atherosclerosis and in humans [19-21]. In particular, statins have been shown to inhibit key pro-oxidant enzymes such as nicotinamide adenine dinucleotide phosphate (NADPH) oxidase [22,23], reduce the synthesis of the highly reactive compound malondialdehyde from lipid peroxidation of polyunsaturated fatty acids [24], as well as increase the expression, activity, and coupling of endothelial nitric oxide synthase [25], and upregulate antioxidant enzymes such as catalase [26], glutathione peroxidase (GPx) [27], and superoxide dismutase (SOD) [28-30]. Notably, epidemiological studies have convincingly shown that higher circulating concentrations of the antioxidant enzymes GPx, SOD, and catalase are associated with a significant reduction in the risk of coronary heart disease [31]. This suggests that pharmacological strategies that upregulate these enzymes may exert a key protective role against atherosclerosis and cardiovascular disease.

In order to investigate the complex interplay between statins and antioxidant mechanisms, we conducted a systematic review and meta-analysis of studies reporting on the effects of statin treatment on the circulating concentrations of GPx, SOD, and catalase in patients with different cardiovascular risk profiles. We hypothesised that statin treatment would significantly increase GPx, SOD, and catalase concentrations regardless of specific agents used.

\section{Materials and Methods}

\subsection{Search Strategy and Study Selection}

We searched for articles published in PubMed, Web of Science, and Scopus, from inception to 31 July 2021, using the terms "Glutathione Peroxidase" or "GPx" or "GSHPX" or "Superoxide Dismutase" or "SOD" or "Catalase" and "Statin". The abstracts and articles were screened by two independent investigators. The article references were also searched for additional studies. Pre-defined inclusion criteria were: (a) reporting of GPx and/or SOD and/or catalase concentrations in blood, erythrocytes, plasma, or serum at baseline and after statin treatment; (b) $\geq 10$ participants; (c) English language; and (d) fulltext availability. Data extracted included the country, type of biological matrix, age, sex distribution, GPx, SOD, and catalase concentrations before and after treatment, disease condition studied, statin and dose used, and treatment duration.

The Joanna Briggs Institute (JBI) Critical Appraisal Checklist for analytical studies was used to assess the risk of bias. Scores $\geq 5,4$, and $<4$ indicated low, moderate, and high risk, respectively [32]. The Grading of Recommendations, Assessment, Development and Evaluation (GRADE) working group system was used to assess the certainty of evidence. GRADE considers the study design, the risk of bias, the presence of heterogeneity, the indirectness of evidence, the imprecision of results, the effect size (small, SMD $<0.5$, medium, SMD 0.5-0.8, and large, SMD >0.8) [33], and the publication bias [34-36]. The study was conducted in accordance with the Preferred Reporting Items for Systematic Reviews and Meta-Analyses (PRISMA) 2020 statement on the reporting of systematic reviews and metaanalyses (Supplementary Materials, Tables S1 and S2) [37]. The International Prospective Register of Systematic Reviews (PROSPERO) registration number was CRD42021271589.

\subsection{Statistical Analysis}

Because of the different units of measurement $(\mathrm{U} / \mathrm{mL}, \mathrm{U} / \mathrm{gHb}, \mathrm{nmol} / \mathrm{mg}$, or $\mu \mathrm{mol} / \mathrm{L})$ used to express the concentrations of GPx, SOD, and catalase, standardized mean differences (SMDs) and 95\% confidence intervals (CIs) were calculated to build forest plots of the differences in GPx, SOD, and catalase concentrations before and after statin treatment, with 
a $p$-value $<0.05$ indicating statistical significance. When required, the means and standard deviations were derived from the corresponding medians and interquartile ranges [38], medians and ranges [39], or from graphs using the Graph Data Extractor software. Betweenstudy heterogeneity was assessed using the Q-statistic (significance level set at $p<0.10$ ) and the $\mathrm{I}^{2}$ statistic $\left(\mathrm{I}^{2}<25 \%\right.$, no heterogeneity; $\mathrm{I}^{2}=25-50 \%$, moderate heterogeneity; $\mathrm{I}^{2}=50-75 \%$, large heterogeneity; $\mathrm{I}^{2}>75 \%$, extreme heterogeneity) [40,41]. In the presence of significant heterogeneity, defined as $\mathrm{I}^{2}$ values $\geq 50 \%$, a random-effects model was used. Sensitivity analysis was performed to assess the influence of each study on the overall risk estimate by sequentially removing individual studies [42]. Publication bias was assessed with the Begg's test, the Egger's test (significance level set at $p<0.05$ for both), and the "trim-and-fill" procedure [43-45]. When possible, the effects of individual statins (e.g., lipophilic: atorvastatin, simvastatin, lovastatin, fluvastatin, cerivastatin, and pitavastatin; hydrophilic: rosuvastatin, pravastatin) were assessed and compared. Statistical analyses were performed using Stata 14 software (STATA Corp., College Station, TX, USA).

\section{Results}

\subsection{Study Selection}

We initially identified 1988 articles. A total of 1970 were excluded (duplicates or irrelevant). After reviewing the remaining 18 articles, 3 were further excluded, leaving 15, reporting 17 treatment arms in 773 patients (mean age of 53 years, $54 \%$ males), for final analysis (Figure 1 and Table 1) [27,46-59].

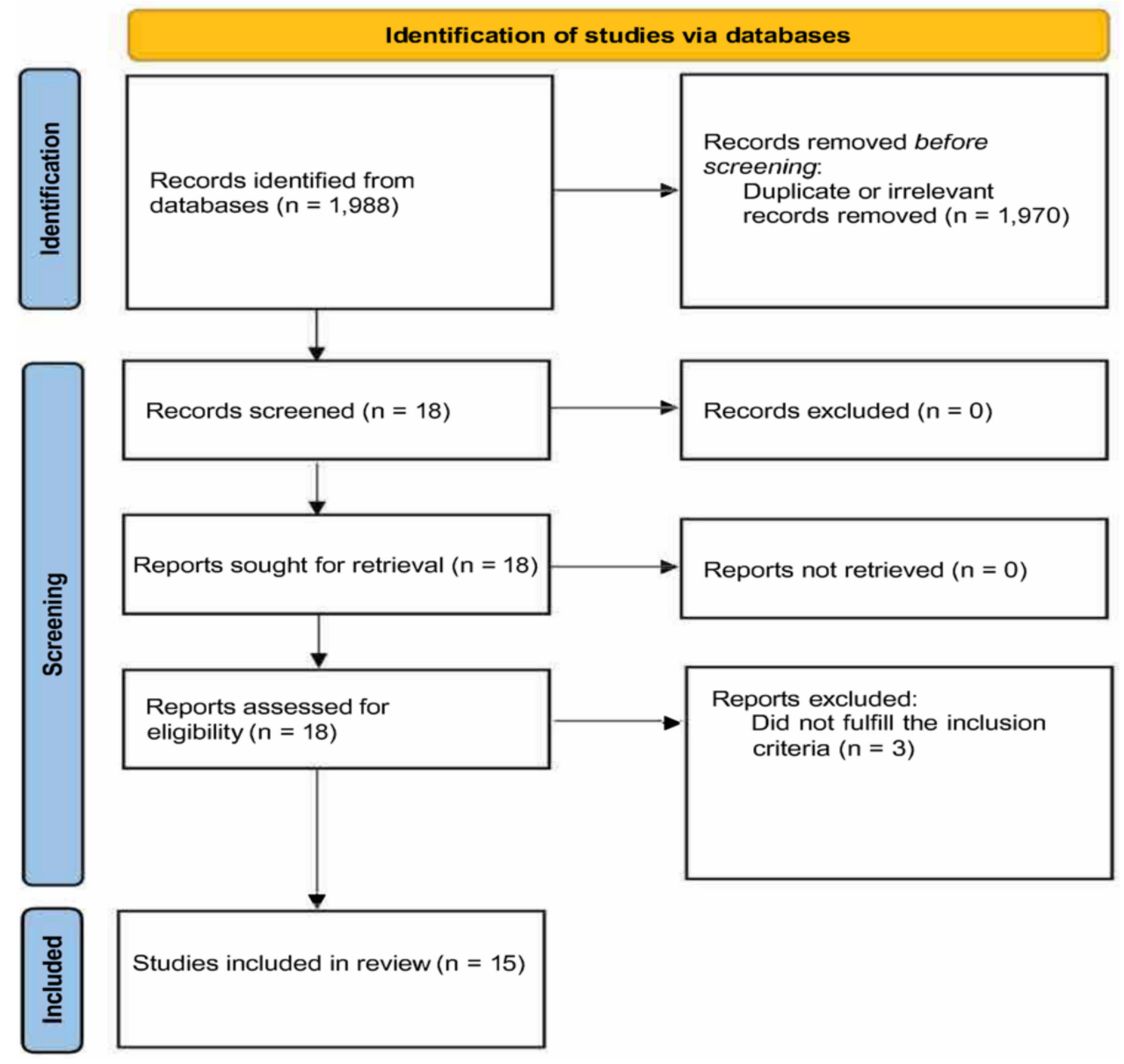

Figure 1. PRISMA 2020 flow diagram. 
Table 1. Study characteristics.

\begin{tabular}{|c|c|c|c|c|c|c|c|c|c|c|c|c|c|}
\hline First Author, Year, Country [Ref] & Matrix & ${ }^{\mathrm{n}}$ & $\begin{array}{c}\text { Age } \\
\text { (yrs) }\end{array}$ & $\mathrm{M} / \mathrm{F}$ & $\begin{array}{c}\text { GPx Bas } \\
\text { Mean } \pm \text { SD }\end{array}$ & $\begin{array}{c}\text { GPX Post } \\
\text { Mean } \pm \text { SD }\end{array}$ & $\begin{array}{c}\text { SOD Bas } \\
\text { Mean } \pm \text { SD }\end{array}$ & $\begin{array}{c}\text { SOD Post } \\
\text { Mean } \pm \text { SD }\end{array}$ & $\begin{array}{c}\text { Cat Bas } \\
\text { Mean } \pm \text { SD }\end{array}$ & $\begin{array}{c}\text { Cat Post } \\
\text { Mean } \pm \text { SD }\end{array}$ & Condition & $\begin{array}{c}\text { Statin and } \\
\text { Daily Dose }\end{array}$ & $\begin{array}{c}\text { Treatmen } \\
\text { (weeks) }\end{array}$ \\
\hline Chen MF, 1997, Taiwan [46] & $\mathrm{P}$ & 20 & 47 & 11/9 & $0.98 \pm 0.32 \mathrm{U} / \mathrm{mL}$ & $1.08 \pm 0.29 \mathrm{U} / \mathrm{mL}$ & NR & NR & NR & $\mathrm{NR}$ & нСL & $\begin{array}{c}\text { Pravastatin } \\
5 \mathrm{mg}\end{array}$ & 12 \\
\hline Yilmaz MI, 2004, Turkey [27] & E & 35 & 48 & $18 / 17$ & $20.93 \pm 10.46 \mathrm{U} / \mathrm{mL}$ & $39.13 \pm 6.76 \mathrm{U} / \mathrm{mL}$ & $510 \pm 190 \mathrm{U} / \mathrm{mL}$ & $589 \pm 182 \mathrm{U} / \mathrm{mL}$ & NR & NR & HCL & $\begin{array}{c}\text { Fluvastatin } \\
40 \mathrm{mg}\end{array}$ & 12 \\
\hline Ghayour-Mobarhan M, 1997, UK [47] & s & 11 & 52 & $7 / 4$ & $0.36 \pm 0.13 \mathrm{U} / \mathrm{mL}$ & $0.32 \pm 0.13 \mathrm{U} / \mathrm{mL}$ & NR & NR & NR & $\mathrm{NR}$ & HCL & $\begin{array}{c}\text { Simvastatin } \\
10 \mathrm{mg}\end{array}$ & 16 \\
\hline Molcányiová A, 2006, Slovakia [48] & E & 42 & 60 & $12 / 30$ & $6.03 \pm 2.97 \mathrm{U} / \mathrm{mL}$ & $9.67 \pm 4.27 \mathrm{U} / \mathrm{mL}$ & NR & NR & NR & NR & HCL & $\begin{array}{c}\text { Simvastatin } \\
20 \mathrm{mg}\end{array}$ & 8 \\
\hline Ruiz MC, 2006, Spain [49] & s & 21 & $\mathrm{NR}$ & NR & $74 \pm 22 \mathrm{nmol} / \mathrm{mg}$ & $106 \pm 22 \mathrm{nmol} / \mathrm{mg}$ & $170 \pm 49 \mathrm{U} / \mathrm{mg}$ & $181 \pm 31 \mathrm{U} / \mathrm{mg}$ & $\begin{array}{c}7.48 \pm 0.84 \\
\mathrm{KU} \times 10^{-5} / \mathrm{mg} \\
\end{array}$ & $\begin{array}{c}7.59 \pm 1.38 \\
\mathrm{KU} \times 10^{-5} / \mathrm{mg} \\
\end{array}$ & Kidney $\mathrm{Tx}$ & $\begin{array}{c}\text { Atorvastatin } \\
10-40 \mathrm{mg}\end{array}$ & 24 \\
\hline Su Y, 2010 (a), China [51] & $\mathrm{E}$ & 75 & 55 & $39 / 36$ & $18.96 \pm 1.45 \mu \mathrm{mol} / \mathrm{L}$ & $21.57 \pm 1.63 \mu \mathrm{mol} / \mathrm{L}$ & $65.73 \pm 17.02 \mathrm{mmol} / \mathrm{L}$ & $96.54 \pm 17.34 \mathrm{mmol} / \mathrm{L}$ & NR & $\mathrm{NR}$ & T2D & $\begin{array}{c}\text { Simvastatin } \\
40 \mathrm{mg}\end{array}$ & 12 \\
\hline Su Y, 2010 (b), China [51] & E & 76 & 56 & $43 / 33$ & $17.31 \pm 1.11 \mu \mathrm{mol} / \mathrm{L}$ & $21.28 \pm 0.57 \mu \mathrm{mol} / \mathrm{L}$ & $75.15 \pm 13.31 \mathrm{mmol} / \mathrm{L}$ & $100.23 \pm 15.67 \mathrm{mmol} / \mathrm{L}$ & NR & NR & $\mathrm{T} 2 \mathrm{D}$ & $\begin{array}{c}\text { Atorvastatin } \\
10 \mathrm{mg} \\
\end{array}$ & 12 \\
\hline Janic M, 2014, Slovenia [52] & wв & 25 & 44 & $25 / 0$ & $1.10 \pm 0.25 \mathrm{U} / \mathrm{gHb}$ & $1.14 \pm 0.20 \mathrm{U} / \mathrm{gHb}$ & NR & NR & NR & NR & Healthy & $\begin{array}{c}\text { Fluvastatin } \\
10 \mathrm{mg}\end{array}$ & 4.5 \\
\hline Sena-Evangelista KCM, 2015, Brazil [53] & WB & 38 & 63 & $23 / 15$ & $41.33 \pm 9.62 \mathrm{U} / \mathrm{gHb}$ & $44.67 \pm 13.33 \mathrm{U} / \mathrm{gHb}$ & $1415 \pm 340 \mathrm{U} / \mathrm{gHg}$ & $1468 \pm 265 \mathrm{U} / \mathrm{gHg}$ & NR & NR & CAD & $\begin{array}{c}\text { Rosuvastatin } \\
10 \mathrm{mg}\end{array}$ & 16 \\
\hline Yildiz A, 2015, Turkey [54] & E & 18 & 38 & 9/9 & $22.37 \pm 7.99 \mathrm{U} / \mathrm{gHb}$ & $30.7 \pm 13.4 \mathrm{U} / \mathrm{gHb}$ & $19.09 \pm 4.61 \mathrm{U} / \mathrm{gHg}$ & $24.34 \pm 7.99 \mathrm{U} / \mathrm{gHg}$ & NR & $\mathrm{NR}$ & Kidney $\mathrm{Tx}$ & $\begin{array}{c}\text { Fluvastatin } \\
80 \mathrm{mg}\end{array}$ & 4 \\
\hline Fassett RG, 2015, Australia [55] & $\mathrm{P}$ & 47 & 65 & $28 / 19$ & $32.8 \pm 10.1 \mathrm{U} / \mathrm{L}$ & $31.4 \pm 11.1 \mathrm{U} / \mathrm{L}$ & NR & NR & NR & NR & CKD & $\begin{array}{c}\text { Atorvastatin } \\
10 \mathrm{mg}\end{array}$ & 3 years \\
\hline Abdel Magid AM, 2017, Egypt [57] & s & 30 & 51 & $15 / 15$ & $98 \pm 78 \mathrm{U} / \mathrm{L}$ & $142 \pm 133 \mathrm{U} / \mathrm{L}$ & NR & NR & NR & NR & $\mathrm{HD}$ & $\begin{array}{c}\text { Simvastatin } \\
60 \mathrm{mg}^{*}\end{array}$ & 16 \\
\hline Hadzi-Petrushev N, 2018, Macedonia [58] & $\mathrm{s}$ & 20 & 43 & $20 / 0$ & $277 \pm 85 \mathrm{U} / \mathrm{mL}$ & $223 \pm 95 \mathrm{U} / \mathrm{mL}$ & NR & NR & $85 \pm 36 \mathrm{U} / \mathrm{mL}$ & $64 \pm 47 \mathrm{U} / \mathrm{mL}$ & NAFLD & $\begin{array}{l}\text { Atorvastatin } \\
20 \mathrm{mg}\end{array}$ & 12 \\
\hline Mayyas F, 2018 (a), Jordan [59] & $\mathrm{P}$ & 122 & 51 & $81 / 41$ & NR & NR & $28 \pm 6 \mathrm{U} / \mathrm{mL}$ & $69 \pm 44 \mathrm{U} / \mathrm{mL}$ & NR & NR & ASCVD & $\begin{array}{c}\text { Atorvastatin } \\
20 \mathrm{mg}\end{array}$ & 12 \\
\hline Mayyas F, 2018 (b), Jordan [59] & $\mathrm{P}$ & 37 & 51 & $24 / 13$ & NR & NR & $30 \pm 18 \mathrm{U} / \mathrm{mL}$ & $75 \pm 43 \mathrm{U} / \mathrm{mL}$ & NR & NR & ASCVD & $\begin{array}{l}\text { Atorvastatin } \\
40 \mathrm{mg}\end{array}$ & 12 \\
\hline
\end{tabular}

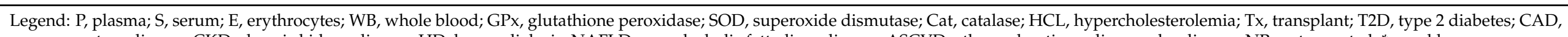
coronary artery disease; CKD, chronic kidney disease; HD, haemodialysis; NAFLD, non-alcoholic fatty liver disease; ASCVD, atherosclerotic cardiovascular disease; NR, not reported; *, weekly. 


\subsection{Glutathione Peroxidase}

\subsubsection{Study Characteristics}

A total of 13 studies, reporting 14 treatment arms in 558 patients (mean age 54 years, $52 \%$ males), presented data on GPx concentrations $[27,46-55,57,58]$. Erythrocytes were assessed in five studies (six arms) [27,48,50,51,54], whole blood in two [52,53], serum in four $[47,49,57,58]$, and plasma in the remaining two $[46,55]$. The statin used was atorvastatin in four studies [49-51,58], simvastatin in four $[47,48,51,57]$, fluvastatin in three $[27,52,54]$, and pravastatin [46] and rosuvastatin [53] in one, respectively. Treatment duration ranged between four weeks and three years (Table 1).

\subsubsection{Risk of Bias}

The risk of bias was low in 11 studies $[27,46,48-51,53-55,57,58]$ and high in the remaining $2[47,52]$ (Table 2).

Table 2. The Joanna Briggs Institute Critical Appraisal Checklist.

\begin{tabular}{|c|c|c|c|c|c|c|c|c|c|}
\hline Study & $\begin{array}{l}\text { Were the } \\
\text { Criteria for } \\
\text { Inclusion in } \\
\text { the Sample } \\
\text { Clearly } \\
\text { Defined? }\end{array}$ & $\begin{array}{l}\text { Were the } \\
\text { Study } \\
\text { Subjects } \\
\text { and the } \\
\text { Setting } \\
\text { Described } \\
\text { in Detail? }\end{array}$ & $\begin{array}{c}\text { Was the } \\
\text { Exposure } \\
\text { Measured } \\
\text { in a Valid } \\
\text { and } \\
\text { Reliable } \\
\text { Way? }\end{array}$ & $\begin{array}{c}\text { Were } \\
\text { Objective, } \\
\text { Standard } \\
\text { Criteria } \\
\text { Used for } \\
\text { Measurement } \\
\text { of the } \\
\text { Condition? }\end{array}$ & $\begin{array}{c}\text { Were } \\
\text { Confounding } \\
\text { Factors } \\
\text { Identified? }\end{array}$ & $\begin{array}{l}\text { Were } \\
\text { Strategies to } \\
\text { Deal with } \\
\text { Confounding } \\
\text { Factors } \\
\text { Stated? }\end{array}$ & $\begin{array}{l}\text { Were the } \\
\text { Outcomes } \\
\text { Measured in } \\
\text { a Valid and } \\
\text { Reliable } \\
\text { Way? }\end{array}$ & $\begin{array}{c}\text { Was } \\
\text { Appropriate } \\
\text { Statistical } \\
\text { Analysis } \\
\text { Used? }\end{array}$ & $\begin{array}{c}\text { Risk of } \\
\text { Bias }\end{array}$ \\
\hline \multirow{15}{*}{$\begin{array}{l}\text { Chen MF [46] } \\
\text { Yilmaz MI [27] } \\
\text { Ghayour-Mobarhan } \\
\text { M [47] } \\
\text { Molčányiová A [48] } \\
\text { Ruiz MC [49] } \\
\text { Save V [50] } \\
\text { Su Y [51] } \\
\text { Janic M [52] } \\
\text { Sena-Evangelista } \\
\text { KCM [53] } \\
\text { Yildiz A [54] } \\
\text { Fassett RG [55] } \\
\text { Hernandez-Mijares } \\
\text { A [56] } \\
\text { Abdel Magid AM } \\
\text { [57] } \\
\text { Hadzi-Petrushev N } \\
\text { [58] } \\
\text { Mayyas F [59] }\end{array}$} & Yes & Yes & Yes & Yes & No & No & Yes & No & Low \\
\hline & Yes & Yes & Yes & Yes & No & No & Yes & No & Low \\
\hline & No & No & Yes & Yes & No & No & Yes & No & High \\
\hline & Yes & Yes & Yes & Yes & Yes & Yes & Yes & Yes & Low \\
\hline & Yes & Yes & Yes & Yes & No & No & Yes & No & Low \\
\hline & Yes & Yes & Yes & Yes & No & No & Yes & No & Low \\
\hline & Yes & Yes & Yes & Yes & No & No & Yes & No & Low \\
\hline & No & No & Yes & Yes & No & No & Yes & No & High \\
\hline & Yes & Yes & Yes & Yes & No & No & Yes & No & Low \\
\hline & Yes & Yes & Yes & Yes & No & No & Yes & No & Low \\
\hline & Yes & Yes & Yes & Yes & No & No & Yes & No & Low \\
\hline & Yes & Yes & Yes & Yes & No & No & Yes & No & Low \\
\hline & Yes & Yes & Yes & Yes & No & No & Yes & No & Low \\
\hline & Yes & Yes & Yes & Yes & No & No & Yes & No & Low \\
\hline & Yes & Yes & Yes & Yes & No & No & Yes & No & Low \\
\hline
\end{tabular}

\subsubsection{Results of Individual Studies and Syntheses}

The forest plot of the GPx concentrations before and after statin treatment is shown in Figure 2. In 10 treatment arms [27,46,48,49,51-54,57], the circulating GPx concentrations were higher after statin treatment (mean difference range, 0.18 to 4.50 ), with a significant difference reported in six $[27,48,49,51,54]$. By contrast, in four arms $[47,50,55,58]$, the GPx concentrations were lower after treatment (mean difference range, -0.13 to -0.60 ), with a significant difference reported in one [50]. Random-effects models were used in view of the extreme heterogeneity observed $\left(\mathrm{I}^{2}=96.0 \%, p<0.001\right)$. Pooled results showed that circulating GPx concentrations were significantly higher after statin treatment (SMD $=0.80$, $95 \%$ CI 0.13 to $1.46, p=0.018$ ). In sensitivity analysis, the corresponding pooled SMD values were not substantially modified when individual studies were sequentially removed (effect size range between 0.52 and 0.91, Figure 3). 


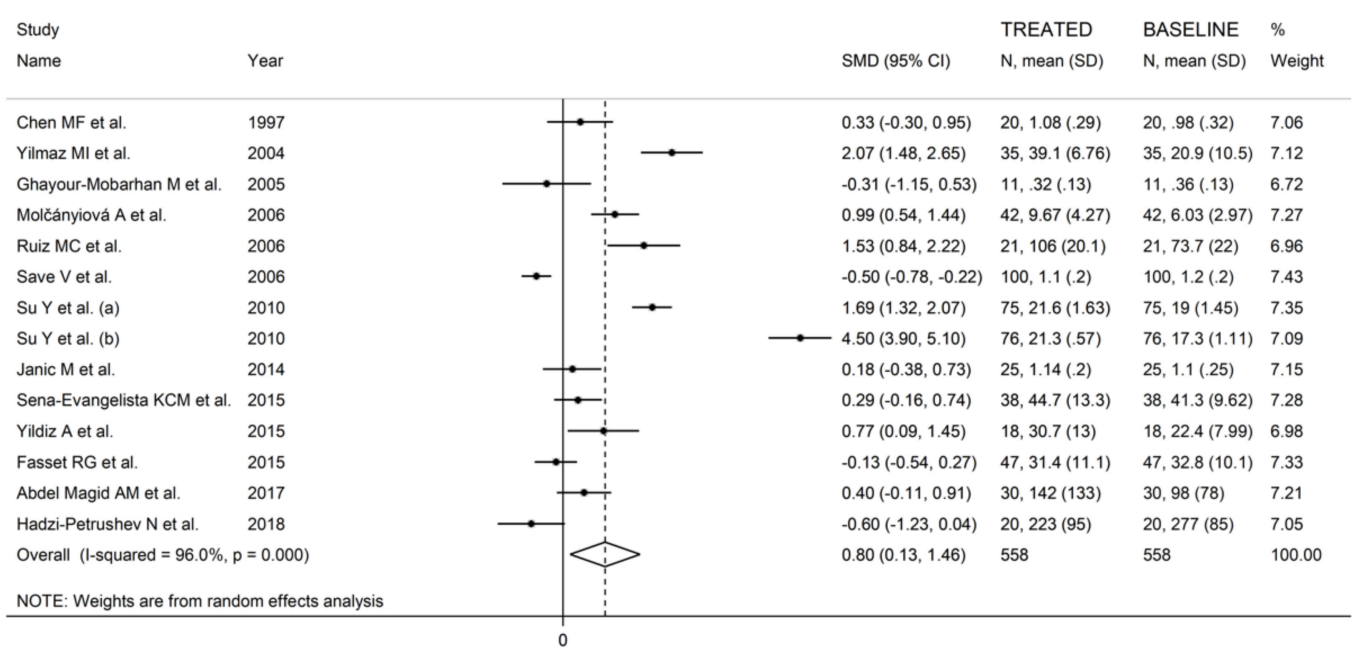

Figure 2. Forest plot of studies reporting GPx concentrations before and after statin treatment.

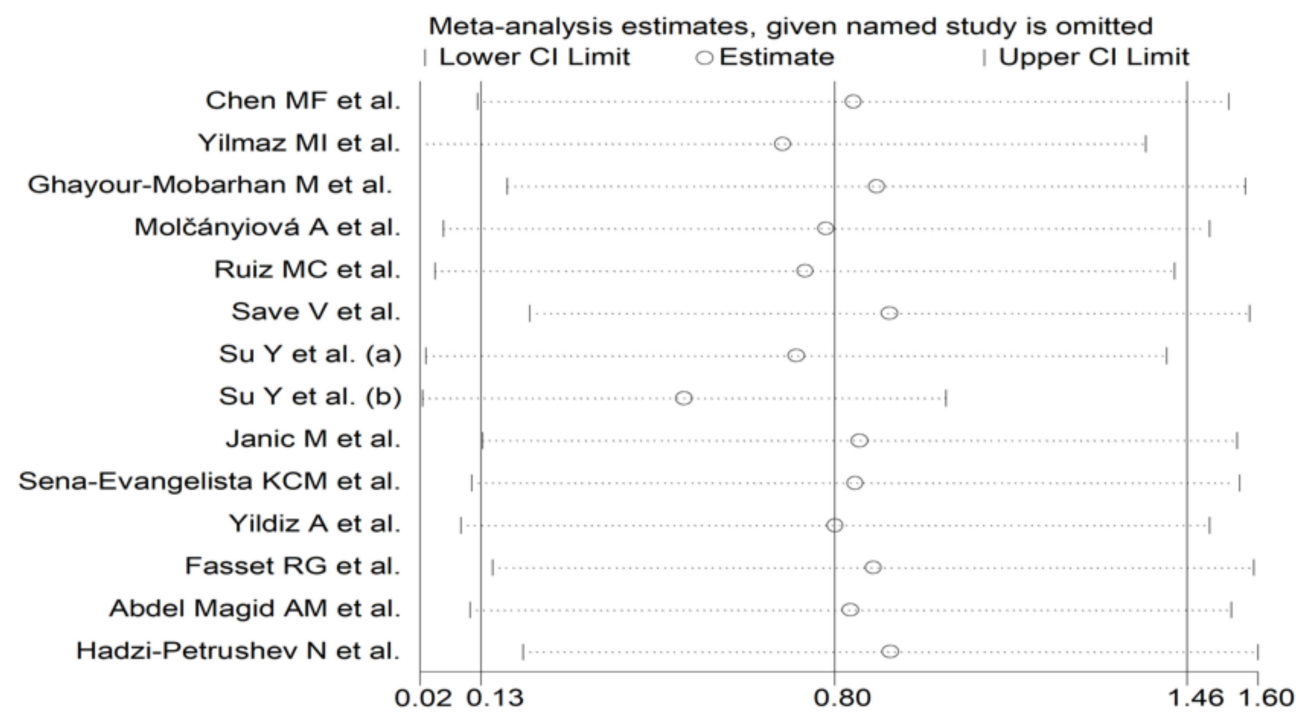

Figure 3. Influence of individual studies on the standardized mean difference (SMD). The hollow circles represent the SMD when the remaining study is omitted.

\subsubsection{Publication Bias}

There was no publication bias according to the Begg's test $(p=0.66)$, the Egger's test $(p=0.24)$, or the "trim-and-fill" method.

\subsubsection{Sub-Group Analysis}

Circulating GPx concentrations were significantly higher after statin treatment in the studies assessing whole blood/erythrocytes (SMD $=1.24,95 \%$ CI 0.22 to $2.26, p=0.017$; $\mathrm{I}^{2}=97.5 \%, p<0.001$, Figure $\left.4 \mathrm{~A}\right)$, but not in those assessing serum/plasma (SMD = 0.20, $95 \%$ CI -0.34 to $\left.0.74, p=0.463 ; \mathrm{I}^{2}=80.0 \%, p<0.001\right)$. Specifically, GPx concentrations post-treatment were significantly higher in the studies assessing erythrocytes (SMD = 1.24, $95 \%$ CI 0.22 to $2.26, p=0.021 ; \mathrm{I}^{2}=98.1 \%, p<0.001$, Figure $\left.4 \mathrm{~B}\right)$, but not in those assessing whole blood $\left(\mathrm{SMD}=0.24,95 \% \mathrm{CI}-0.11\right.$ to $\left.0.59, p=0.174 ; \mathrm{I}^{2}=97.5 \%, p<0.001\right)$. In studies assessing erythrocytes, the SMD with individual statins (fluvastatin, simvastatin, atorvastatin) was similar (Figure 5). 


\begin{tabular}{|c|c|c|}
\hline $\begin{array}{l}\text { Study } \\
\text { Name }\end{array}$ & SMD $(95 \% \mathrm{Cl})$ & $\begin{array}{l}\% \\
\text { Weight }\end{array}$ \\
\hline \multicolumn{3}{|l|}{ Serum/Plasma } \\
\hline Chen MF et al. & $0.33(-0.30,0.95)$ & 7.06 \\
\hline Ghayour-Mobarhan M et al. & $-0.31(-1.15,0.53)$ & 6.72 \\
\hline Ruiz MC et al. & $1.53(0.84,2.22)$ & 6.96 \\
\hline Fasset RG et al. & $-0.13(-0.54,0.27)$ & 7.33 \\
\hline Abdel Magid AM et al. & $0.40(-0.11,0.91)$ & 7.21 \\
\hline Hadzi-Petrushev $\mathrm{N}$ et al. & $-0.60(-1.23,0.04)$ & 7.05 \\
\hline Subtotal (I-squared $=80.0 \%, p=0.000)$ & $0.20(-0.34,0.74)$ & 42.32 \\
\hline \multicolumn{3}{|l|}{ Whole Blood/Erythrocytes } \\
\hline Yilmaz Ml et al. & $2.07(1.48,2.65)$ & 7.12 \\
\hline Molčányiová A et al. & $0.99(0.54,1.44)$ & 7.27 \\
\hline Save $\mathrm{V}$ et al. & $-0.50(-0.78,-0.22)$ & 7.43 \\
\hline Su Y et al. (a) & $1.69(1.32,2.07)$ & 7.35 \\
\hline Su Y et al. (b) & $\rightarrow 4.50(3.90,5.10)$ & 7.09 \\
\hline Janic M et al. & $0.18(-0.38,0.73)$ & 7.15 \\
\hline Sena-Evangelista KCM et al. & $0.29(-0.16,0.74)$ & 7.28 \\
\hline Yildiz A et al. & $0.77(0.09,1.45)$ & 6.98 \\
\hline Subtotal $(\mathrm{I}-$ squared $=97.5 \%, \mathrm{p}=0.000)$ & $1.24(0.22,2.26)$ & 57.68 \\
\hline Overall $(\mathrm{I}-$ squared $=96.0 \%, \mathrm{p}=0.000)$ & $0.80(0.13,1.46)$ & 100.00 \\
\hline \multicolumn{3}{|l|}{ NOTE: Weights are from random effects analysis } \\
\hline \multicolumn{3}{|c|}{0} \\
\hline Study & & $\%$ \\
\hline Name & SMD $(95 \% \mathrm{Cl})$ & Weight \\
\hline \multicolumn{3}{|l|}{ Erythrocytes } \\
\hline Yilmaz Ml et al. & $2.07(1.48,2.65)$ & 12.38 \\
\hline Molčányiová A et al. & $0.99(0.54,1.44)$ & 12.58 \\
\hline Save $\mathrm{V}$ et al. & $-0.50(-0.78,-0.22)$ & 12.78 \\
\hline Su Y et al. (a) & $1.69(1.32,2.07)$ & 12.68 \\
\hline Su $Y$ et al. (b) & $\rightarrow 4.50(3.90,5.10)$ & 12.35 \\
\hline Yildiz A et al. & $0.77(0.09,1.45)$ & 12.21 \\
\hline Subtotal $(\mathrm{I}-$ squared $=98.1 \%, \mathrm{p}=0.000)$ & $1.58(0.23,2.92)$ & 74.99 \\
\hline & & \\
\hline \multicolumn{3}{|l|}{ Whole Blood } \\
\hline Janic $\mathrm{M}$ et al. & $0.18(-0.38,0.73)$ & 12.43 \\
\hline Sena-Evangelista $\mathrm{KCM}$ et al. & $0.29(-0.16,0.74)$ & 12.58 \\
\hline Subtotal $(\mathrm{I}-$ squared $=0.0 \%, \mathrm{p}=0.762)$ & $0.24(-0.11,0.59)$ & 25.01 \\
\hline Overall $(\mathrm{I}-$-squared $=97.5 \%, \mathrm{p}=0.000)$ & $1.24(0.22,2.26)$ & 100.00 \\
\hline NOTE: Weights are from random effects analysis & & \\
\hline
\end{tabular}

Figure 4. Forest plot of studies investigating GPx concentrations according to biological matrix: (A) whole blood/erythrocytes vs. plasma/serum; (B) whole blood vs. erythrocytes. 


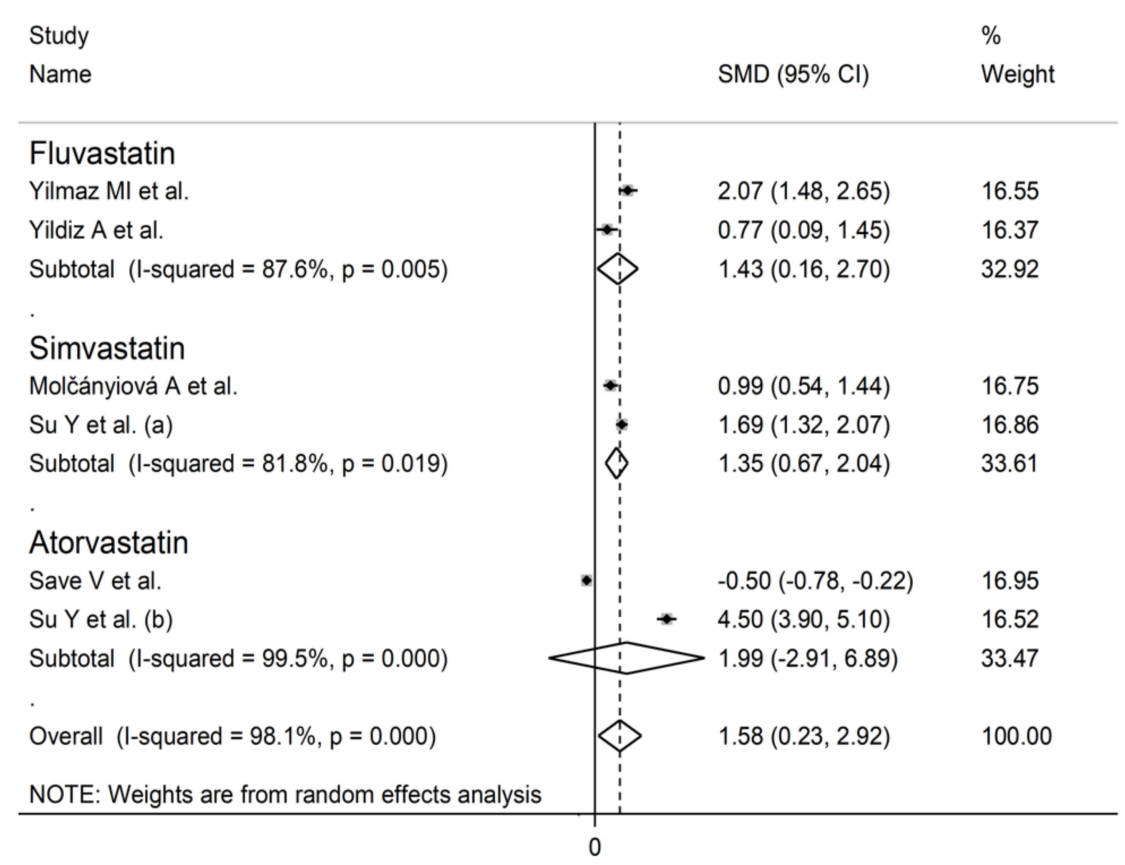

Figure 5. Forest plot of studies of individual statins on GPx concentrations.

\subsubsection{Certainty of Evidence}

The initial level of certainty for GPx SMD values was moderate as the studies were interventional (rating $3, \oplus \oplus \oplus \ominus$ ). As 11 out of 13 studies had a low risk of bias (no rating change required), there was extreme and unexplained heterogeneity (serious limitation, downgrade one level), there was a lack of indirectness (no rating change required), the imprecision was low (narrow confidence intervals without threshold crossing, upgrade one level), the effect size was large (SMD $=0.80$, upgrade one level), and there was no publication bias (no rating change required), the overall level of certainty was considered high (rating $4, \oplus \oplus \oplus \oplus$ ).

\subsection{Superoxide Dismutase}

\subsubsection{Study Characteristics}

A total of 8 studies, reporting 10 treatment arms in 542 patients (mean age 53 years, $52 \%$ males), presented data on SOD [27,49-51,53,54,56,59]. Four studies (five arms) assessed erythrocytes [27,50,51,54], two serum [49,56], and one whole blood [53] and plasma [59], respectively. The statin used was atorvastatin in four studies [49-51,59], simvastatin in two [51,56], fluvastatin in two [27,54], and rosuvastatin in one [53]. The treatment duration ranged between 4 and 24 weeks (Table 1 ).

\subsubsection{Risk of Bias}

The risk of bias was low in all studies $[27,49-51,53,54,56,59]$ (Table 2).

\subsubsection{Results of Individual Studies and Syntheses}

The forest plot of the circulating SOD concentrations before and after statin treatment is shown in Figure 6. In all treatment arms, SOD concentrations were higher after statin treatment (mean difference range 0.27 to 6.95), with significant differences reported in seven arms $[50,51,54,56,59]$. In view of the extreme heterogeneity observed $\left(\mathrm{I}^{2}=96.9 \%\right.$, $p<0.001)$, random-effects models were used. Pooled results showed that the circulating SOD concentrations were significantly higher after statin treatment $(\mathrm{SMD}=1.54,95 \% \mathrm{CI}$ 0.71 to $2.36, p<0.001)$. In the sensitivity analysis, the pooled SMD values were not modified when individual studies were omitted (effect size range between 0.98 and 1.69, Figure 7). 


\begin{tabular}{|c|c|c|c|c|c|}
\hline \multicolumn{3}{|l|}{ Study } & TREATED & \multirow{2}{*}{$\begin{array}{l}\text { BASELINE } \\
\mathrm{N}, \text { mean }(\mathrm{SD})\end{array}$} & \multirow{2}{*}{$\begin{array}{l}\% \\
\text { Weight }\end{array}$} \\
\hline Name & Year & SMD $(95 \% \mathrm{Cl})$ & $\mathrm{N}$, mean (SD) & & \\
\hline Yilmaz Ml et al. & 2004 & $0.46(-0.02,0.93)$ & $35,589(152)$ & $35,510(190)$ & 10.08 \\
\hline Ruiz MC et al. & 2006 & $0.27(-0.34,0.88)$ & $21,181(31)$ & $21,170(49)$ & 9.87 \\
\hline Save $V$ et al. & 2005 & $\longrightarrow-6.95(6.22,7.69)$ & $100,6260(375)$ & $100,3673(369)$ & 9.63 \\
\hline Su Y et al. (a) & 2010 & $1.79(1.41,2.17)$ & $75,96.5(17.3)$ & $75,65.7(17)$ & 10.20 \\
\hline Su Y et al. (b) & 2010 & $1.73(1.35,2.10)$ & $76,100(15.7)$ & $76,75.2(13.3)$ & 10.21 \\
\hline Sena-Evangelista KCM et al. & 2015 & $0.17(-0.28,0.62)$ & $38,1468(265)$ & $38,1415(340)$ & 10.11 \\
\hline Yildiz A et al. & 2015 & $0.80(0.12,1.49)$ & $18,24.3(7.99)$ & $18,19.1(4.61)$ & 9.74 \\
\hline Hernandez-Mijares A et al. & 2016 & $0.68(0.04,1.32)$ & $20, .92(.18)$ & $20, .81(.14)$ & 9.82 \\
\hline Mayyas $\mathrm{F}$ et al. (a) & 2018 & $1.31(1.03,1.58)$ & $122,69(44)$ & $122,28(6)$ & 10.31 \\
\hline Mayyas F et al. (b) & 2018 & $1.37(0.86,1.87)$ & $37,75(43)$ & $37,30(18)$ & 10.03 \\
\hline \multicolumn{2}{|c|}{ Overall $(I-$ squared $=96.9 \%, p=0.000)$} & $1.54(0.71,2.36)$ & 542 & 542 & 100.00 \\
\hline NOTE: Weights are from rand & m effects analysis & & & & \\
\hline
\end{tabular}

Figure 6. Forest plot of SOD concentrations before and after statin treatment.

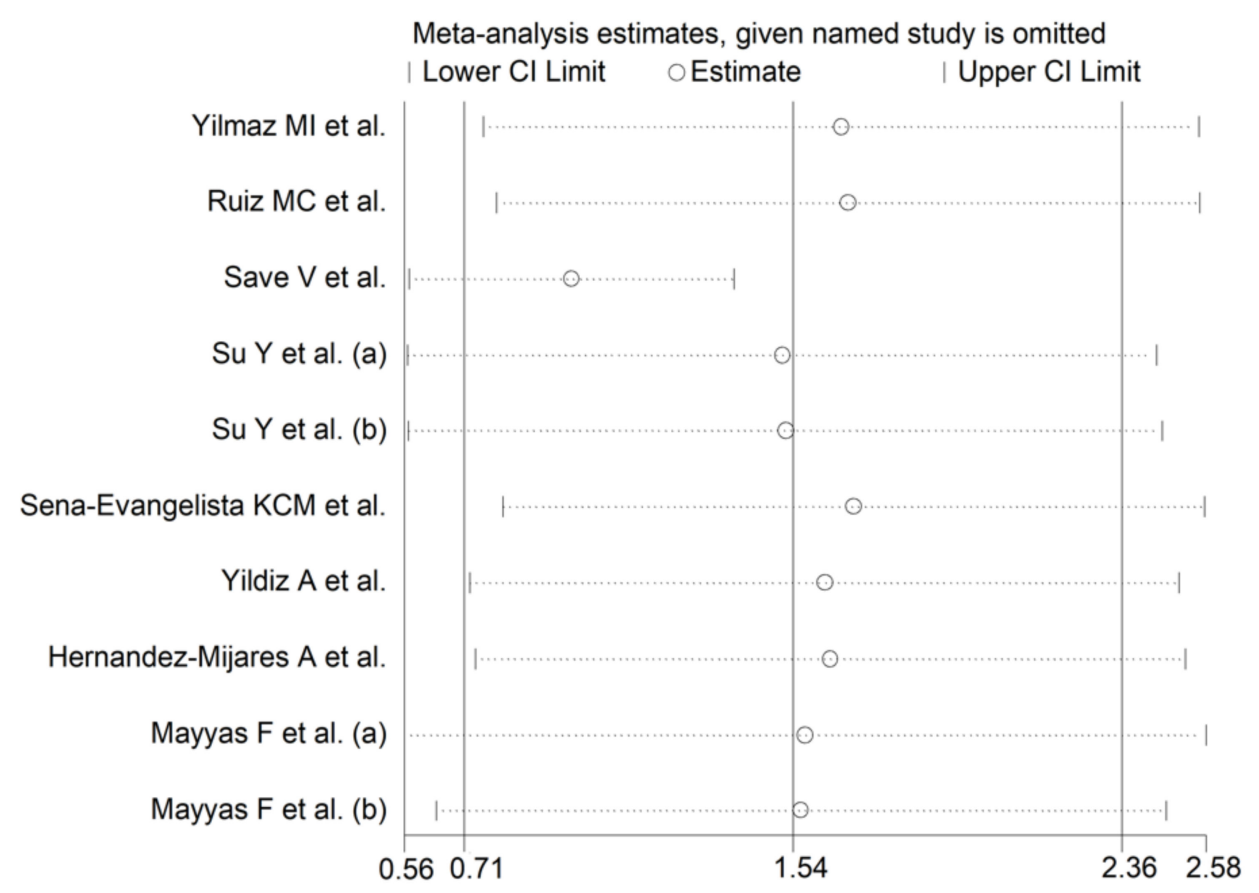

Figure 7. Sensitivity analysis describing the impact of individual studies on SOD on the standardized mean difference.

\subsubsection{Publication Bias}

No publication bias was observed with either the Begg's test $(p=0.72)$, the Egger's test $(p=0.61)$, or the "trim-and-fill" method.

\subsubsection{Sub-Group Analysis}

Post-treatment SOD concentrations were significantly higher both in studies assessing whole blood/erythrocytes $\left(\mathrm{SMD}=1.97,95 \%\right.$ CI 0.54 to $3.40, p<0.001 ; \mathrm{I}^{2}=98.1 \%, p<0.001$, Figure $8 \mathrm{~A}$ ) and in those assessing serum/plasma (SMD $=0.95,95 \%$ CI 0.47 to $1.44, p<0.001$; $\left.\mathrm{I}^{2}=75.0 \%, p<0.001\right)$. Non-significant differences in SMD $(\mathrm{t}=-3.33, p=0.08)$ were observed between studies measuring SOD in plasma $(\mathrm{SMD}=1.32,95 \%$ CI 1.08 to $1.56, p<0.001$, 
Figure $8 \mathrm{~B})$ and those assessing serum (SMD $=0.47,95 \% \mathrm{CI} 0.02$ to $0.91, p=0.038)$. In both cases, however, no heterogeneity was observed $\left(\mathrm{I}^{2}=0.0 \%\right)$. The SMD with individual statins (fluvastatin, simvastatin, atorvastatin) was similar (Figure 9).

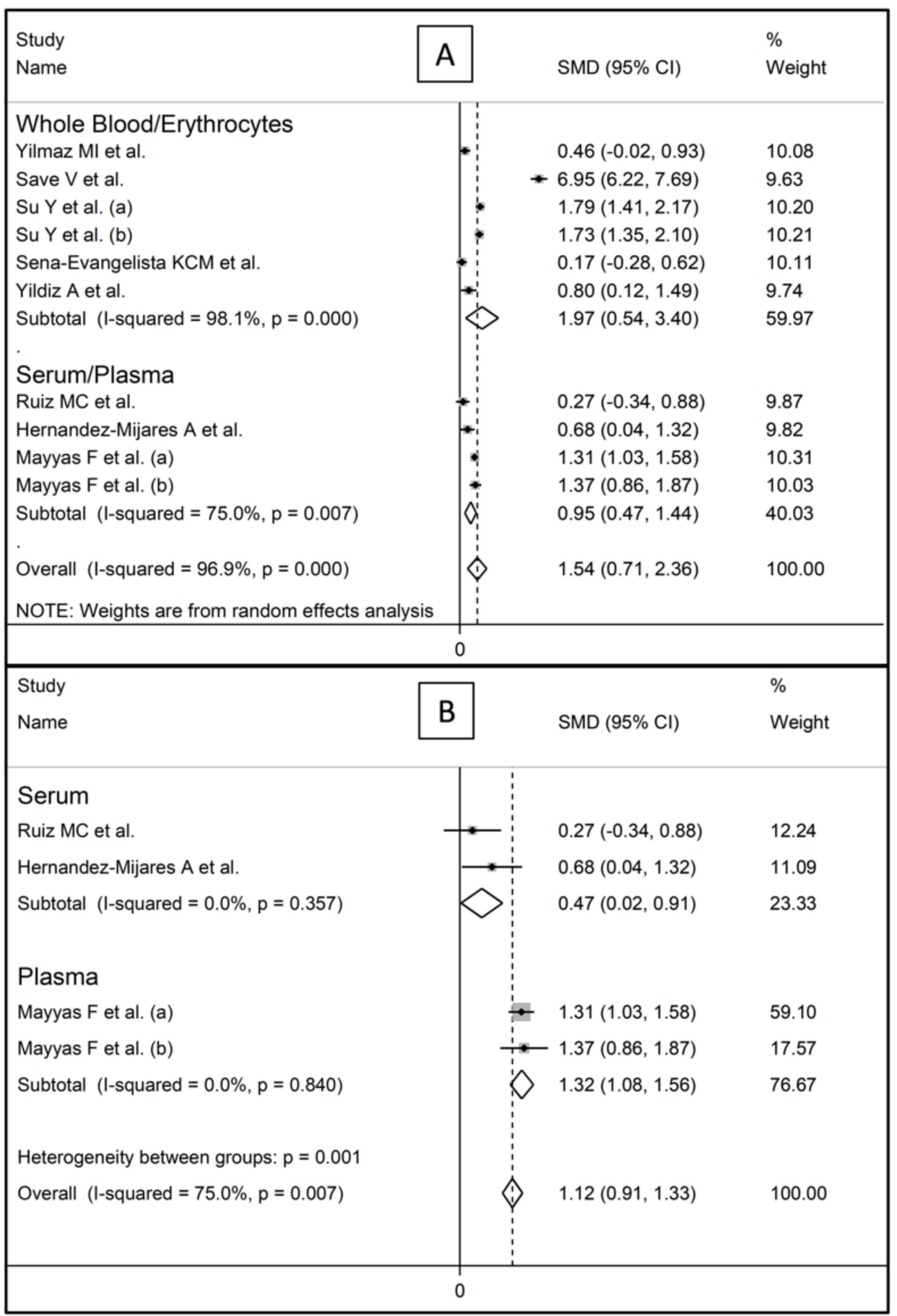

Figure 8. Forest plot of studies investigating SOD concentrations according to the biological matrix: (A) whole blood/erythrocytes vs. plasma/serum; (B) plasma vs. serum. 


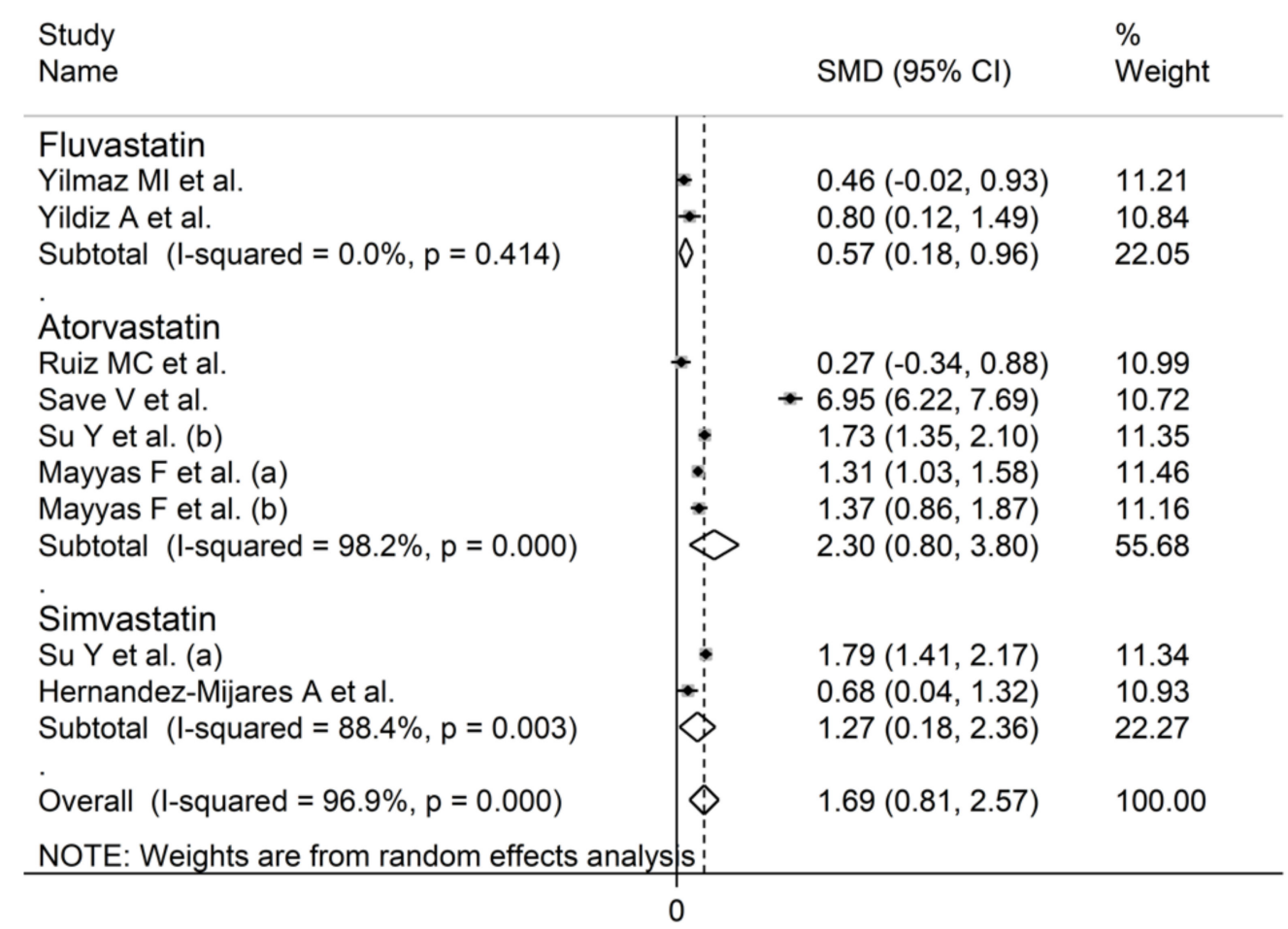

Figure 9. Forest plot of studies of individual statins on SOD concentrations.

\subsubsection{Certainty of Evidence}

The initial certainty for the SOD SMD values was moderate (interventional studies; rating $3, \oplus \oplus \oplus \ominus$ ). The final level of certainty was high (rating $4, \oplus \oplus \oplus \oplus$ ) due to the low risk of bias in all studies (no rating change), the extreme and unexplained heterogeneity (downgrade one level), the lack of indirectness (no rating change), the low imprecision (upgrade one level), the large effect size (SMD = 1.54, upgrade one level), and the absence of publication bias (no rating change).

\subsection{Catalase}

\subsubsection{Study Characteristics}

A total of 3 studies, reporting 4 treatment arms in 61 patients (mean age 51 years, $63 \%$ males), presented data on serum catalase $[49,56,58]$. The statin used was atorvastatin in two studies $[49,58]$, and simvastatin in the remaining one [56]. The treatment duration ranged between 4 and 24 weeks (Table 1).

\subsubsection{Risk of Bias}

The risk of bias was considered low in all studies $[49,56,58]$ (Table 2).

\subsubsection{Results of Individual Studies and Syntheses}

The forest plot of the circulating catalase concentrations before and after statin treatment is shown in Figure 10. The catalase concentrations increased in one study [49], and decreased in the other two [56,58]. However, in no study was a significant difference reported. Accordingly, the pooled results showed that the circulating catalase concentrations did not significantly change after statin treatment (SMD $=-0.16,95 \%$ CI -0.51 to 0.20 , $p=0.391)$. There was a low between-study heterogeneity $\left(\mathrm{I}^{2}=0.00 \%, p=0.391\right)$. In the sensitivity analysis, the corresponding pooled SMD values were not substantially modified when individual studies were sequentially omitted (effect size range between -0.29 and 0.00, Figure 11). 


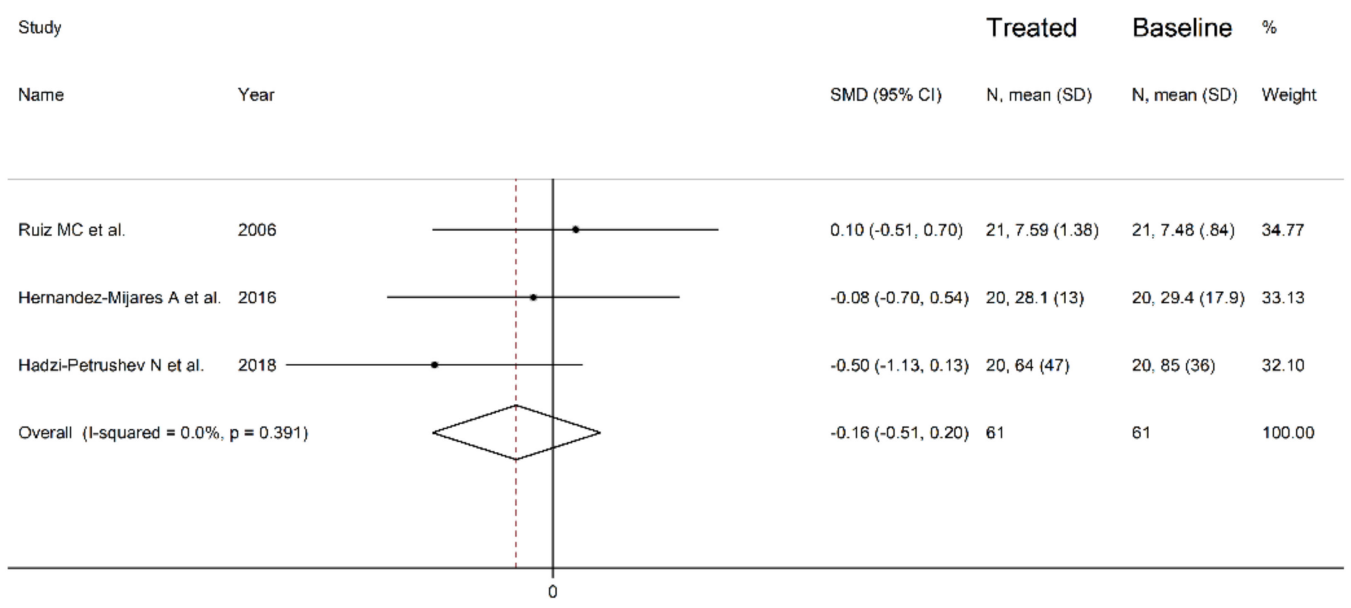

Figure 10. Forest plot of catalase concentrations before and after statin treatment.

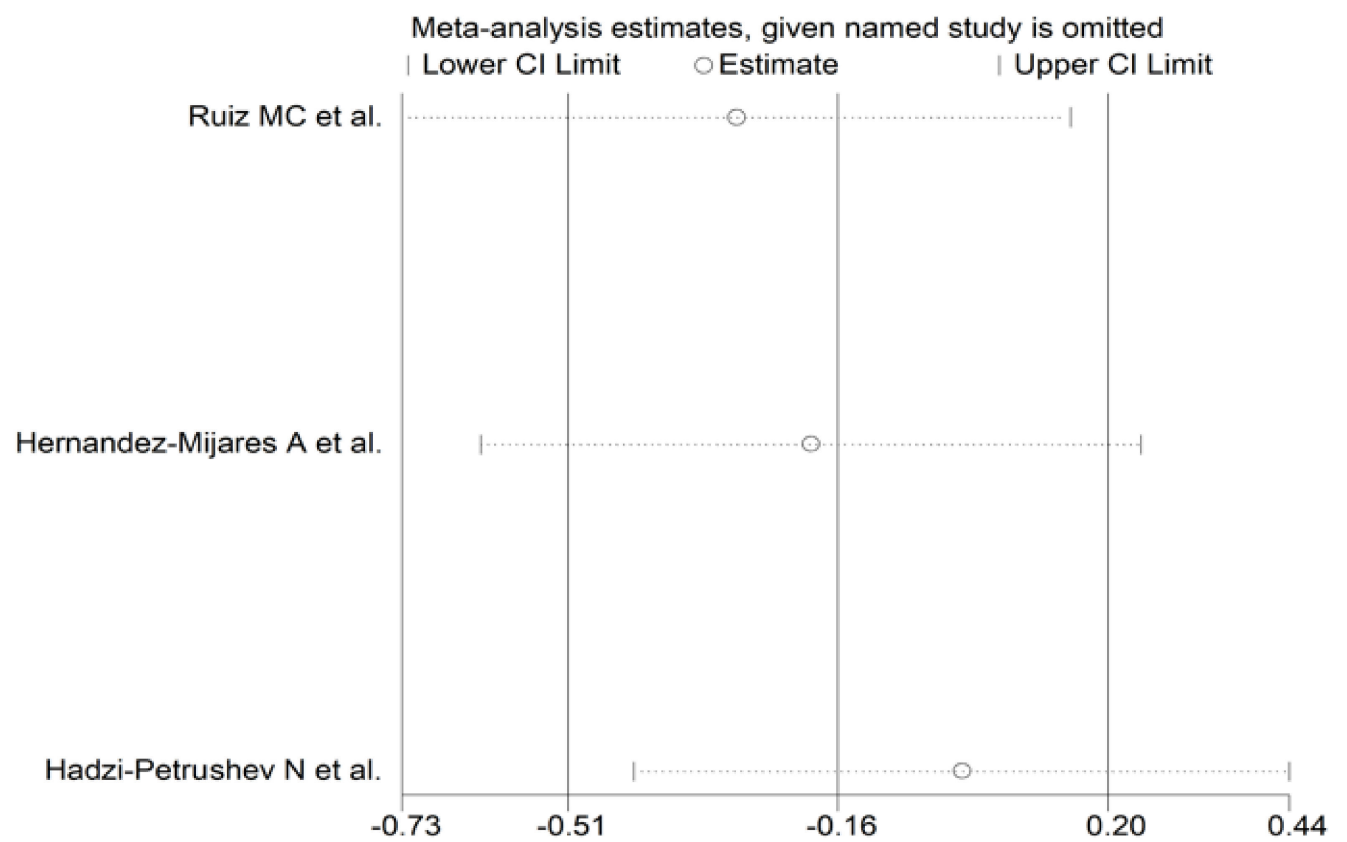

Figure 11. Sensitivity analysis of the influence of each study on the overall standardized mean difference.

\subsubsection{Publication Bias}

An assessment of publication bias was not possible due to the limited number of studies.

\subsubsection{Sub-Group Analysis}

A sub-group analysis was not possible due to the limited number of studies.

\subsubsection{Certainty of Evidence}

The initial level of certainty was moderate as the studies were interventional (rating 3 , $\oplus \oplus \oplus \ominus$ ). This was downgraded to very low (rating $0, \ominus \ominus \ominus \ominus$ ) after considering the low risk of bias in all studies (no change), the low heterogeneity (no change), the lack of indirectness (no change), the high imprecision (downgrade one level), the small effect size (SMD $=-0.16$, downgrade one level), and the lack of assessment of publication bias (downgrade one level). 


\section{Discussion}

Statins significantly increased the circulating concentrations of the antioxidant enzymes GPx and SOD, but not catalase, in patients with various cardiovascular risk burdens. The observed SMD values for GPx (0.80) and SOD (1.54) suggest a large effect size, and therefore the presence of tangible antioxidant effects [33]. Furthermore, in sensitivity analysis, the corresponding pooled SMDs were not substantially modified when individual studies were sequentially removed. Importantly, the certainty of evidence was considered high for both GPx and SOD.

The presence of hypercholesterolemia, singly or in combination with other traditional cardiovascular risk factors, favours the production of ROS by NADPH oxidase, xanthine oxidase, the mitochondrial electron-transport chain, and uncoupled nitric oxide synthase $[60,61]$. This, in combination with an impaired function of key antioxidant systems that include GPx, SOD, and catalase, promotes oxidative stress and, consequently, the development of endothelial dysfunction, vascular damage, and atherosclerosis [30,62]. The main biological effects of GPx, SOD, and catalase are well established. GPx catalyses the reduction of free $\mathrm{H}_{2} \mathrm{O}_{2}$, a precursor of the highly reactive radical $\mathrm{OH}^{\bullet}$, to $\mathrm{H}_{2} \mathrm{O}$ and their corresponding alcohols. While eight isoforms of GPx have been reported in humans (GPx1-8), GPx1 is the most abundant and commonly measured isoform [63]. The three isoforms of SOD (SOD1-3) catalyse the dismutation of the superoxide anion, $\mathrm{O}_{2}{ }^{-}$, into $\mathrm{O}_{2}$ and $\mathrm{H}_{2} \mathrm{O}_{2}$ [64]. By contrast, catalase, a tetramer of four polypeptides, promotes the transformation of $\mathrm{H}_{2} \mathrm{O}_{2}$ into $\mathrm{O}_{2}$ and $\mathrm{H}_{2} \mathrm{O}$ [65]. The key pathophysiological role of GPx, $\mathrm{SOD}$, and catalase in human atherosclerosis was highlighted in a systematic review and meta-analysis of 3 cohort and 41 case-control studies. The pooled odds ratio for coronary heart disease was significantly and inversely associated with a 1-standard deviation increase in GPx $(0.51,95 \%$ CI 0.35 to 0.75$)$, SOD $(0.48,95 \%$ CI 0.32 to 0.72$)$, and catalase (0.32, $95 \%$ CI 0.16 to 0.61 ) [31]. The associations with GPx and SOD were similar in patients with acute and chronic coronary heart disease. By contrast, the associations with catalase were stronger in patients with acute coronary heart disease [31].

Our meta-analysis supports a significant antioxidant effect of statins through the upregulation of GPx and SOD. The absence of tangible effects of statin treatment on the concentrations of catalase needs to be interpreted with caution due to the small number of eligible studies identified $(n=3)$. While these data are encouraging in terms of atheroprotection, the exact mechanisms involved in the statin-mediated upregulation of antioxidant enzymes require additional in vitro and in vivo studies. Furthermore, appropriately designed interventional studies are warranted to determine whether the beneficial effects of this class of drugs in terms of primary and secondary cardiovascular prevention are, at least partly, mediated by specific antioxidant effects that are independent of cholesterol lowering.

The relatively small number of studies identified for analysis and the extreme betweenstudy heterogeneity when reporting GPx and SOD concentrations represent the significant limitations of our study. However, virtually no heterogeneity was observed in a subgroup of studies investigating SOD concentrations specifically in serum of plasma. Additional limitations include the different biological matrices used for the assessment of GPx and SOD, and the lack of serial assessment of these enzymes throughout the treatment period. Significant strengths include the lack of publication bias and the high certainty of evidence with GPx and SOD, suggesting that the effect of statins on these enzymes is both genuine and biologically plausible.

\section{Conclusions}

Statin treatment significantly increases the circulating concentrations of the antioxidant enzymes GPx and SOD using a range of biological matrices, suggesting the protective effects of these agents against oxidative stress. Intervention studies are warranted to investigate the antioxidant effects of statins as important mediators of their beneficial effects for primary and secondary cardiovascular prevention, to determine the most suitable biological matrix for GPx and SOD assessment, and to identify specific patient groups that 
are more likely to benefit from a combined antioxidant and the lipid-lowering effect of this class of drugs.

Supplementary Materials: The following are available online at https://www.mdpi.com/article/ 10.3390/antiox10111841/s1: Table S1: PRISMA 2020 abstract checklist; and Table S2: PRISMA 2020 checklist and search strategy.

Author Contributions: A.Z. and A.A.M. designed the study, screened the articles, assessed the risk of bias, extracted the data, and analysed and interpreted the data. A.A.M. wrote the first draft of the manuscript. A.A.M. and A.Z. reviewed the subsequent versions and the final draft. All authors have read and agreed to the published version of the manuscript.

Funding: This research received no external funding.

Conflicts of Interest: The authors declare no conflict of interest.

\section{References}

1. Lu, H.; Daugherty, A. Atherosclerosis. Arterioscler. Thromb. Vasc. Biol. 2015, 35, 485-491. [CrossRef] [PubMed]

2. Michos, E.D.; McEvoy, J.W.; Blumenthal, R.S. Lipid Management for the Prevention of Atherosclerotic Cardiovascular Disease. N. Engl. J. Med. 2019, 381, 1557-1567. [CrossRef]

3. Cai, T.; Abel, L.; Langford, O.; Monaghan, G.; Aronson, J.K.; Stevens, R.J.; Lay-Flurrie, S.; Koshiaris, C.; McManus, R.J.; Hobbs, F.R.; et al. Associations between statins and adverse events in primary prevention of cardiovascular disease: Systematic review with pairwise, network, and dose-response meta-analyses. BMJ 2021, 374, n1537. [CrossRef] [PubMed]

4. Sirtori, C.R. The pharmacology of statins. Pharmacol. Res. 2014, 88, 3-11. [CrossRef]

5. Oesterle, A.; Laufs, U.; Liao, J.K. Pleiotropic Effects of Statins on the Cardiovascular System. Circ. Res. 2017, 120, 229-243. [CrossRef]

6. Kouhpeikar, H.; Delbari, Z.; Sathyapalan, T.; Simental-Mendia, L.E.; Jamialahmadi, T.; Sahebkar, A. The Effect of Statins through Mast Cells in the Pathophysiology of Atherosclerosis: A Review. Curr. Atheroscler. Rep. 2020, 22, 19. [CrossRef] [PubMed]

7. Bahrami, A.; Parsamanesh, N.; Atkin, S.L.; Banach, M.; Sahebkar, A. Effect of statins on toll-like receptors: A new insight to pleiotropic effects. Pharmacol. Res. 2018, 135, 230-238. [CrossRef]

8. John, S.; Schneider, M.P.; Delles, C.; Jacobi, J.; Schmieder, R.E. Lipid-independent effects of statins on endothelial function and bioavailability of nitric oxide in hypercholesterolemic patients. Am. Heart J. 2005, 149, 473. [CrossRef]

9. Tsiara, S.; Elisaf, M.; Mikhailidis, D.P. Early vascular benefits of statin therapy. Curr. Med. Res. Opin. 2003, 19, 540-556. [CrossRef]

10. Ray, K.K.; Cannon, C.P. Early time to benefit with intensive statin treatment: Could it be the pleiotropic effects? Am. J. Cardiol. 2005, 96, 54F-60F. [CrossRef]

11. Walter, D.H. Insights into early and rapid effects of statin therapy after coronary interventions. Curr. Pharm. Des. 2004, 10, 369-373. [CrossRef] [PubMed]

12. Marchio, P.; Guerra-Ojeda, S.; Vila, J.M.; Aldasoro, M.; Victor, V.M.; Mauricio, M.D. Targeting Early Atherosclerosis: A Focus on Oxidative Stress and Inflammation. Oxid. Med. Cell. Longev. 2019, 2019, 8563845. [CrossRef] [PubMed]

13. Ahotupa, M. Oxidized lipoprotein lipids and atherosclerosis. Free Radic. Res. 2017, 51, 439-447. [CrossRef]

14. Khatana, C.; Saini, N.K.; Chakrabarti, S.; Saini, V.; Sharma, A.; Saini, R.V.; Saini, A.K. Mechanistic Insights into the Oxidized Low-Density Lipoprotein-Induced Atherosclerosis. Oxid. Med. Cell. Longev. 2020, 2020, 5245308. [CrossRef] [PubMed]

15. Forstermann, U.; Xia, N.; Li, H. Roles of Vascular Oxidative Stress and Nitric Oxide in the Pathogenesis of Atherosclerosis. Circ. Res. 2017, 120, 713-735. [CrossRef]

16. Khosravi, M.; Poursaleh, A.; Ghasempour, G.; Farhad, S.; Najafi, M. The effects of oxidative stress on the development of atherosclerosis. Biol. Chem. 2019, 400, 711-732. [CrossRef]

17. Yang, X.; Li, Y.; Li, Y.; Ren, X.; Zhang, X.; Hu, D.; Gao, Y.; Xing, Y.; Shang, H. Oxidative Stress-Mediated Atherosclerosis: Mechanisms and Therapies. Front. Physiol. 2017, 8, 600. [CrossRef]

18. Napoli, C.; Lerman, L.O. Involvement of oxidation-sensitive mechanisms in the cardiovascular effects of hypercholesterolemia. Mayo Clin. Proc. 2001, 76, 619-631. [CrossRef]

19. Rosenson, R.S. Statins in atherosclerosis: Lipid-lowering agents with antioxidant capabilities. Atherosclerosis 2004, 173, 1-12. [CrossRef]

20. Hermida, N.; Balligand, J.L. Low-density lipoprotein-cholesterol-induced endothelial dysfunction and oxidative stress: The role of statins. Antioxid. Redox Signal. 2014, 20, 1216-1237. [CrossRef]

21. Margaritis, M.; Channon, K.M.; Antoniades, C. Statins as regulators of redox state in the vascular endothelium: Beyond lipid lowering. Antioxid. Redox Signal. 2014, 20, 1198-1215. [CrossRef]

22. Colucci, R.; Fornai, M.; Duranti, E.; Antonioli, L.; Rugani, I.; Aydinoglu, F.; Ippolito, C.; Segnani, C.; Bernardini, N.; Taddei, S.; et al. Rosuvastatin prevents angiotensin II-induced vascular changes by inhibition of NAD(P)H oxidase and COX-1. Br. J. Pharmacol. 2013, 169, 554-566. [CrossRef] [PubMed] 
23. Rueckschloss, U.; Galle, J.; Holtz, J.; Zerkowski, H.R.; Morawietz, H. Induction of NAD(P)H oxidase by oxidized low-density lipoprotein in human endothelial cells: Antioxidative potential of hydroxymethylglutaryl coenzyme A reductase inhibitor therapy. Circulation 2001, 104, 1767-1772. [CrossRef] [PubMed]

24. Zinellu, A.; Paliogiannis, P.; Usai, M.F.; Carru, C.; Mangoni, A.A. Effect of statin treatment on circulating malondialdehyde concentrations: A systematic review and meta-analysis. Ther. Adv. Chronic. Dis. 2019, 10, 2040622319862714. [CrossRef]

25. Margaritis, M.; Sanna, F.; Antoniades, C. Statins and oxidative stress in the cardiovascular system. Curr. Pharm. Des. 2017, 23, 7040-7047. [CrossRef] [PubMed]

26. Ota, H.; Eto, M.; Kano, M.R.; Kahyo, T.; Setou, M.; Ogawa, S.; Iijima, K.; Akishita, M.; Ouchi, Y. Induction of endothelial nitric oxide synthase, SIRT1, and catalase by statins inhibits endothelial senescence through the Akt pathway. Arterioscler. Thromb. Vasc. Biol. 2010, 30, 2205-2211. [CrossRef]

27. Yilmaz, M.I.; Baykal, Y.; Kilic, M.; Sonmez, A.; Bulucu, F.; Aydin, A.; Sayal, A.; Kocar, I.H. Effects of statins on oxidative stress. Biol. Trace Elem. Res. 2004, 98, 119-127. [CrossRef]

28. Landmesser, U.; Bahlmann, F.; Mueller, M.; Spiekermann, S.; Kirchhoff, N.; Schulz, S.; Manes, C.; Fischer, D.; de Groot, K.; Fliser, D.; et al. Simvastatin versus ezetimibe: Pleiotropic and lipid-lowering effects on endothelial function in humans. Circulation 2005, 111, 2356-2363. [CrossRef]

29. Carrepeiro, M.M.; Rogero, M.M.; Bertolami, M.C.; Botelho, P.B.; Castro, N.; Castro, I.A. Effect of n-3 fatty acids and statins on oxidative stress in statin-treated hypercholestorelemic and normocholesterolemic women. Atherosclerosis 2011, 217, 171-178. [CrossRef] [PubMed]

30. Li, H.; Horke, S.; Forstermann, U. Oxidative stress in vascular disease and its pharmacological prevention. Trends Pharmacol. Sci. 2013, 34, 313-319. [CrossRef]

31. Flores-Mateo, G.; Carrillo-Santisteve, P.; Elosua, R.; Guallar, E.; Marrugat, J.; Bleys, J.; Covas, M.I. Antioxidant enzyme activity and coronary heart disease: Meta-analyses of observational studies. Am. J. Epidemiol. 2009, 170, 135-147. [CrossRef]

32. Moola, S.; Munn, Z.; Tufanaru, C.; Aromataris, E.; Sears, K.; Sfetcu, R.; Currie, M.; Lisy, K.; Qureshi, R.; Mattis, P.; et al. Systematic reviews of etiology and risk. In Joanna Briggs Institute Reviewer's Manual; Aromataris, E., Munn, Z., Eds.; Johanna Briggs Institute: Adelaide, Australia, 2017.

33. Cohen, J. Statistical Power Analysis for the Behavioral Sciences, 2nd ed.; Erlbaum: Hillsdale, NJ, USA, 1988.

34. Balshem, H.; Helfand, M.; Schünemann, H.J.; Oxman, A.D.; Kunz, R.; Brozek, J.; Vist, G.E.; Falck-Ytter, Y.; Meerpohl, J.; Norris, S.; et al. GRADE guidelines: 3. Rating the quality of evidence. J. Clin. Epidemiol. 2011, 64, 401-406. [CrossRef] [PubMed]

35. Hultcrantz, M.; Rind, D.; Akl, E.A.; Treweek, S.; Mustafa, R.A.; Iorio, A.; Alper, B.S.; Meerpohl, J.J.; Murad, M.H.; Ansari, M.T.; et al. The GRADE Working Group clarifies the construct of certainty of evidence. J. Clin. Epidemiol. 2017, 87, 4-13. [CrossRef]

36. Zhang, Y.; Coello, P.A.; Guyatt, G.H.; Yepes-Nuñez, J.J.; Akl, E.A.; Hazlewood, G.; Pardo-Hernandez, H.; Etxeandia-Ikobaltzeta, I.; Qaseem, A.; Williams, J.W., Jr.; et al. GRADE guidelines: 20. Assessing the certainty of evidence in the importance of outcomes or values and preferences-inconsistency, imprecision, and other domains. J. Clin. Epidemiol. 2019, 111, 83-93. [CrossRef] [PubMed]

37. Page, M.J.; McKenzie, J.E.; Bossuyt, P.M.; Boutron, I.; Hoffmann, T.C.; Mulrow, C.D.; Shamseer, L.; Tetzlaff, J.M.; Akl, E.A.; Brennan, S.E.; et al. The PRISMA 2020 statement: An updated guideline for reporting systematic reviews. BMJ 2021, 372, n71. [CrossRef]

38. Wan, X.; Wang, W.; Liu, J.; Tong, T. Estimating the sample mean and standard deviation from the sample size, median, range and/or interquartile range. BMC Med. Res. Methodol. 2014, 14, 135. [CrossRef]

39. Hozo, S.P.; Djulbegovic, B.; Hozo, I. Estimating the mean and variance from the median, range, and the size of a sample. BMC Med. Res. Methodol. 2005, 5, 13. [CrossRef]

40. Bowden, J.; Tierney, J.F.; Copas, A.J.; Burdett, S. Quantifying, displaying and accounting for heterogeneity in the meta-analysis of RCTs using standard and generalised Q statistics. BMC Med. Res. Methodol. 2011, 11, 41. [CrossRef]

41. Higgins, J.P.; Thompson, S.G. Quantifying heterogeneity in a meta-analysis. Stat. Med. 2002, 21, 1539-1558. [CrossRef]

42. Tobias, A. Assessing the influence of a single study in the meta-analysis estimate. Stata Tech. Bull. 1999, $47,15-17$.

43. Begg, C.B.; Mazumdar, M. Operating characteristics of a rank correlation test for publication bias. Biometrics 1994, 50, 1088-1101. [CrossRef] [PubMed]

44. Sterne, J.A.; Egger, M. Funnel plots for detecting bias in meta-analysis: Guidelines on choice of axis. J. Clin. Epidemiol. 2001, 54, 1046-1055. [CrossRef]

45. Duval, S.; Tweedie, R. Trim and fill: A simple funnel-plot-based method of testing and adjusting for publication bias in meta-analysis. Biometrics 2000, 56, 455-463. [CrossRef]

46. Chen, M.F.; Hsu, H.C.; Lee, Y.T. Short-term treatment with low-dose pravastatin attenuates oxidative susceptibility of low-density lipoprotein in hypercholesterolemic patients. Cardiovasc. Drugs Ther. 1997, 11, 787-793. [CrossRef]

47. Ghayour-Mobarhan, M.; Lamb, D.J.; Taylor, A.; Vaidya, N.; Livingstone, C.; Wang, T.; Ferns, G.A. Effect of statin therapy on serum trace element status in dyslipidaemic subjects. J. Trace Elem. Med. Biol. 2005, 19, 61-67. [CrossRef]

48. Molcanyiova, A.; Stancakova, A.; Javorsky, M.; Tkac, I. Beneficial effect of simvastatin treatment on LDL oxidation and antioxidant protection is more pronounced in combined hyperlipidemia than in hypercholesterolemia. Pharmacol. Res. 2006, 54, 203-207. [CrossRef]

49. Ruiz, M.C.; Moreno, J.M.; Ruiz, N.; Vargas, F.; Asensio, C.; Osuna, A. Effect of statin treatment on oxidative stress and renal function in renal transplantation. Transplant. Proc. 2006, 38, 2431-2433. [CrossRef] [PubMed] 
50. Save, V.; Patil, N.; Moulik, N.; Rajadhyaksha, G. Effect of atorvastatin on type 2 diabetic dyslipidemia. J. Cardiovasc. Pharmacol. Ther. 2006, 11, 262-270. [CrossRef] [PubMed]

51. Su, Y.; Xu, Y.; Sun, Y.M.; Li, J.; Liu, X.M.; Li, Y.B.; Liu, G.D.; Bi, S. Comparison of the effects of simvastatin versus atorvastatin on oxidative stress in patients with type 2 diabetes mellitus. J. Cardiovasc. Pharmacol. 2010, 55, 21-25. [CrossRef] [PubMed]

52. Janic, M.; Lunder, M.; Prezelj, M.; Sabovic, M. A combination of low-dose fluvastatin and valsartan decreases inflammation and oxidative stress in apparently healthy middle-aged males. J. Cardiopulm. Rehabil. Prev. 2014, 34, 208-212. [CrossRef]

53. Sena-Evangelista, K.C.M.; Pedrosa, L.F.C.; Paiva, M.S.M.O.; Dias, P.C.S.; Ferreira, D.Q.C.; Cozzolino, S.M.F.; Faulin, T.E.S.; Abdalla, D.S.P. The hypolipidemic and pleiotropic effects of rosuvastatin are not enhanced by its association with zinc and selenium supplementation in coronary artery disease patients: A double blind randomized controlled study. PLOS ONE 2015, 10, e0119830. [CrossRef] [PubMed]

54. Yildiz, A.; Gul, C.B.; Ocak, N.; Ersoy, A.L.P.A.R.S.L.A.N.; Sag, S.; Oruc, A.; Ayar, Y.; Dagel, T.; Dirican, M.; Gullulu, M. Fluvastatin Decreases Oxidative Stress in Kidney Transplant Patients. Transplant. Proc. 2015, 47, 2870-2874. [CrossRef] [PubMed]

55. Fassett, R.G.; Robertson, I.K.; Ball, M.J.; Geraghty, D.P.; Coombes, J.S. Effects of atorvastatin on oxidative stress in chronic kidney disease. Nephrology 2015, 20, 697-705. [CrossRef] [PubMed]

56. Hernandez-Mijares, A.; Bañuls, C.; Rovira-Llopis, S.; Diaz-Morales, N.; Escribano-Lopez, I.; de Pablo, C.; Alvarez, A.; Veses, S.; Rocha, M.; Victor, V.M. Effects of simvastatin, ezetimibe and simvastatin/ezetimibe on mitochondrial function and leukocyte/endothelial cell interactions in patients with hypercholesterolemia. Atherosclerosis 2016, 247, 40-47. [CrossRef]

57. Abdel Magid, A.M.; Abbassi, M.M.; Iskander, E.E.M.; Mohamady, O.; Farid, S.F. Randomized comparative efficacy and safety study of intermittent simvastatin versus fenofibrate in hemodialysis. J. Comp. Eff. Res. 2017, 6, 413-424. [CrossRef] [PubMed]

58. Hadzi-Petrushev, N.; Dimovska, K.; Jankulovski, N.; Mitrov, D.; Mladenov, M. Supplementation with Alpha-Tocopherol and Ascorbic Acid to Nonalcoholic Fatty Liver Disease's Statin Therapy in Men. Adv. Pharmacol. Sci. 2018, 2018, 4673061. [CrossRef]

59. Mayyas, F.; Baydoun, D.; Ibdah, R.; Ibrahim, K. Atorvastatin Reduces Plasma Inflammatory and Oxidant Biomarkers in Patients With Risk of Atherosclerotic Cardiovascular Disease. J. Cardiovasc. Pharmacol. Ther. 2018, 23, 216-225. [CrossRef] [PubMed]

60. Oliveira, H.C.F.; Vercesi, A.E. Mitochondrial bioenergetics and redox dysfunctions in hypercholesterolemia and atherosclerosis. Mol. Asp. Med. 2020, 71, 100840. [CrossRef] [PubMed]

61. Sozen, E.; Ozer, N.K. Impact of high cholesterol and endoplasmic reticulum stress on metabolic diseases: An updated mini-review. Redox Biol. 2017, 12, 456-461. [CrossRef]

62. Thomas, S.R.; Witting, P.K.; Drummond, G.R. Redox control of endothelial function and dysfunction: Molecular mechanisms and therapeutic opportunities. Antioxid. Redox Signal. 2008, 10, 1713-1765. [CrossRef]

63. Lubos, E.; Loscalzo, J.; Handy, D.E. Glutathione peroxidase-1 in health and disease: From molecular mechanisms to therapeutic opportunities. Antioxid. Redox Signal. 2011, 15, 1957-1997. [CrossRef] [PubMed]

64. Sheng, Y.; Abreu, I.A.; Cabelli, D.E.; Maroney, M.J.; Miller, A.F.; Teixeira, M.; Valentine, J.S. Superoxide dismutases and superoxide reductases. Chem. Rev. 2014, 114, 3854-3918. [CrossRef] [PubMed]

65. Nandi, A.; Yan, L.J.; Jana, C.K.; Das, N. Role of Catalase in Oxidative Stress- and Age-Associated Degenerative Diseases. Oxid. Med. Cell. Longev. 2019, 2019, 9613090. [CrossRef] [PubMed] 